Technical Report 1037

\title{
Practical Thinking: Innovation in Battle Command Instruction
}

\author{
Jon J. Fallesen, Rex R. Michel, \\ James W. Lussier, and Julia Pounds
}

U.S. Army Research Institute

\section{Fort Leavenworth Research Unit Stanley M. Halpin, Chief}

U.S. Army Research Institute for the Behavioral and Social Sciences 5001 Eisenhower Avenue, Alexandria, Virginia 22333-5600

Office, Deputy Chief of Staff for Personnel

Department of the Army

$$
\text { January } 1996
$$

Approved for public releese; distribution is unlimiled. 